\title{
Efek Ekstrak Metanol Daun Ketapang (Terminalia catappa L.) Terhadap Kepadatan Kolagen dalam Penyembuhan Luka Bakar Derajat II pada Tikus Putih (Rattus norvegicus)
}

\section{The Effect of Metanol Extract Ketapang Leaves (Terminalia catappa L.) on Collagen Density in Healing of Second Degree Burns in Albino Rats (Rattus norvegicus)}

\author{
Rangga Yulianto ${ }^{1 *}$, Nusdianto Triakoso², Amung Logam Saputro², Boedi Setiawan², \\ Aditya Yudhana ${ }^{3}$, Bodhi Agustono ${ }^{4}$ \\ ${ }^{1}$ Bachelor of Veterinary Medicine, ${ }^{2}$ Department of Veterinary Clinic, ${ }^{3}$ Department of Veterinary \\ Parasitology, ${ }^{4}$ Department of Animal Husbandry, \\ Faculty of Veterinary Medicine, Universitas Airlangga, \\ UNAIR C-Campus Mulyorejo, Surabaya, Jawa Timur, Indonesia, 60115 \\ *Corresponding author: rangga.yulianto-2015@ fkh.unair.ac.id
}

\begin{abstract}
Abstrak
Tujuan penelitian ini adalah mengetahui pengaruh ekstrak metanol daun ketapang (Terminalia catappa L.) untuk meningkatkan kepadatan serabut kolagen dalam penyembuhan luka bakar derajat II pada tikus putih (Rattus norvegicus). Sebanyak dua puluh ekor tikus puth (Rattus norvegicus) jantan dibagi ke dalam lima kelompok perlakuan yaitu K- luka dengan pemberian basis salep, $\mathrm{K}+$ luka dengan pemberian Bioplacenton ${ }^{\circledR}$, P1 luka bakar dengan pemberian salep ekstrak daun ketapang 25\%, P2 luka bakar dengan pemberian salep ekstrak daun ketapang 50\% dan P3 luka bakar dengan pemberian salep ekstrak daun ketapang 100\%. Terapi diberikan sehari sekali selama tujuh hari. Hasil data rata-rata jumlah kepadatan serabut kolagen menunjukkan K- 83.57\%, K+ 84.52\%, P1 90.32\%, P2 86.77\% dan P3 83.36\%. Kelompok P1 dan P2 tidak memiliki perbedaan yang nyata, tetapi berbeda nyata dengan kelompok $\mathrm{K}+, \mathrm{K}-$ dan P3. Kesimpulan dari penelitian ini ekstrak metanol daun ketapang berpengaruh dalam meningkatkan kepadatan serabut kolagen pada proses penyembuhan luka bakar derajat II.
\end{abstract}

Kata kunci: flavonoid, kepadatan kolagen, luka bakar

Abstract

The aim of this study was to determine the influence of metanol extract ketapang leaves (Terminalia catappa L.) to increase on density of collagen fibers in healing of second degree burns in white rats (Rattus norvegicus). A total of 20 male rats (Rattus norvegicus) were divided into five groups with four mice per group. K- (negative control) was given the injury and then were given ointment. $\mathrm{K}+$ (positive control) was given the injury and then were given Bioplacenton ${ }^{\circledR}$. P1 burns with $25 \%$ metanol extract ketapang leaves ointment. P2 burns with 50\% metanol extract ketapang leaves ointment. P3 burns with 100\% metanol extract ketapang leaves ointment. Treatment was given every other day for fourteen days. The results of the average data on density of collagen fibers showed K- 83.57\%, K+ 84.52\%, P1 90.32\%, P2 86.77\% and P3 83.36\%. P1 and $\mathrm{P} 2$ groups did not show significant differences, but were significantly different from $\mathrm{K}+, \mathrm{K}-$ and $\mathrm{P} 3$ groups. From the results, it can be concluded that ketapang leaves metanol extract can increas on density of collagen fibers in the second degree burns healing process.

Key words: burns, collagen density, flavonoid

\section{PENDAHULUAN}

Kulit adalah bagian tubuh paling luar yang memiliki banyak fungsi diantara lain sebagai pertahanan terhadap lingkungan luar serta tempat sekresi keringat dan minyak. Anjing dan kucing menggunakan kulit mereka sebagai organ yang sangat vital karena selain sebagai termoregulasi tubuh, kulit dijadikan sebagai alat untuk melindungi kaki yang bersinggungan dengan 
tanah secara langsung (Frandson et al., 2009). Kulit yang berada di bagian eksternal tubuh lebih rentan mengalami kerusakan seperti pada luka bakar (Balqis dkk., 2014).

Luka bakar merupakan kerusakan jaringan yang disebabkan oleh beberapa faktor seperti api, bahan kimia, listrik dan radiasi (Balqis dkk., 2014). Angka kejadian luka bakar pada hewan kecil seperti anjing dan kucing jarang terjadi dan jika terjadi kasus luka bakar hal tersebut dikarenakan akibat tindakan yang disengaja ataupun tidak sengaja (Maravelis et al., 2015). Penyembuhan luka bakar berbeda dengan penyembuhan luka insisi. Luka bakar mengakibatkan pembuluh darah mengalami permeabilitas tinggi yang menyebabkan anemia dan menimbulkan edema sehingga timbul bula yang mampu menyebabkan cairan intravaskuler berkurang (Becker, 2006).

Proses penyembuhan luka terdiri dari empat fase yaitu hemostasis, inflamasi, proliferasi, dan maturasi. Fase - fase tersebut saling berkaitan dalam proses penyembuhan luka (McGavin dan James, 2016). Fase yang berperan penting dalam proses penyembuhan luka adalah fase proliferasi. Fase proliferasi berperan dalam proses pembentukan kolagen pada fase proliferasi yang berperan penting dalam tingkat kesembuhan luka (Paramita, 2016).

Penyembuhan luka bakar memiliki dampak negatif jika tidak dilakukan penanganan secara cepat. Pengobatan yang biasa dilakukan sebagai pertolongan pertama dalam kasus luka bakar adalah beberapa produk komersial yang banyak digunakan oleh masyarakat umum seperti Bioplacenton $^{\circledR}$ dan dapat juga menggunakan madu. Efek negatif dari penggunaan Bioplacenton $^{\circledR}$ adalah aktivitas Bioplacenton ${ }^{\circledR}$ dalam penyembuhan kasus luka bakar kurang mampu menyerap eksudat (Ivanalee, 2018). Bioplacenton $^{\circledR}$ juga memiliki daya regeneratif yang rendah (Mawarti, 2012).

Kandungan senyawa seperti flavonoid, tanin dan saponin memiliki peran yang penting (Muhammad dan Mudi, 2011). Flavonoid merupakan senyawa yang mampu menghambat enzim metalloproteinase sehingga kolagen dapat terbentuk (Elliot et al., 2007; Hamid dkk., 2018).
Tanin memiliki efek untuk menstabilkan proses pembentukan kolagen (Nikita dan Meera, 2014) sedangkan saponin mampu mempercepat fase inflamasi dengan menstimulasi vascular endothelial growth factor (VEGF) dan mempercepat proses penyembuhan luka (Rohmah dkk., 2016; Hamid dkk., 2019). Penelitian bertujuan mempelajari pengaruh senyawa-senyawa daun ketapang (Terminalia catappa L.) sebagai alternatif penyembuhan luka bakar perlu dilakukan untuk mengetahui pengaruh salep ekstrak daun ketapang pada luka bakar derajat II dengan pengamatan secara mikroskopis untuk mengetahui gambaran histopatologi proses penyembuhan luka bakar derajat II pada kulit melalui pengamatan pada pembentukan serabut kolagen.

\section{METODE PENELITIAN}

\section{Alat dan Bahan}

Bahan yang digunakan dalam penelitian yaitu 20 ekor tikus putih (Rattus norvegicus) galur wistar umur 8-10 minggu dengan berat 130-140 gram, daun ketapang yang berasal dari UPT Materia Media Batu, Bioplacenton ${ }^{\circledR}, \mathrm{NaCl}$ fisiologis, Xylazine, Ketamin, Sabun Cair, Alkohol 70\%, makanan hewan coba berupa pellet merk All feed-4, air minum, kapas steril, pelarut metanol pro analis, aquades, adeps lanae dan vaselin flavum.

Alat yang digunakan yaitu timbangan digital, rotatory evaporator ,labu penguapan, vacum pump, tabung buchner, corong buchner, kertas saring, beaker glass $100 \mathrm{ml}$, mortar, stamper, sudip, spatel, pot salep, penimbang berat badan tikus, kandang box tikus, alas kandang menggunakan serbuk kayu steril, tempat makan dan minum, sarung tangan kain, glove karet, blade no. 11, blade no. 20 scalpel no. 3 dan no. 4 , spuit $1 \mathrm{ml}$, jarum suntik tuberculin, pinset anatomis, penggaris, kasa steril, alat pencukur bulu, under pads (sensipads),cotton bud, gunting dan mikroskop trinokuler.

\section{Perlakuan}

Penelitian ini menggunakan Rancangan Acak Lengkap (RAL) yang terdiri dari lima 
kelompok perlakuan yaitu yaitu K- luka bakar derajat II dengan pemberian basis salep, $\mathrm{K}+$ luka bakar derajat II dengan pemberian Bioplacenton $^{\circledR}$, P1 luka bakar derajat II dengan pemberian salep ekstrak daun ketapang 25\%, P2 luka bakar derajat II dengan pemberian salep ekstrak daun ketapang 50\% dan luka bakar derajat II dengan pemberian salep ekstrak daun ketapang $100 \%$. Setiap kelompok perlakuan terdiri dari empat ekor tikus. Terapi dilakukan sehari sekali selama empat belas hari. Pengamatan dilakukan pada hari ke 15 setelah pembuatan luka bakar.

\section{Analis is Data}

Analisis data yang digunakan terhadap perhitungan jumlah kepadatan serabut kolagen pada sediaan preparat histopatologi ini yaitu uji Kruskal-Wallis dan dilanjutkan dengan uji Mann-Whitney dengan derajat kemaknaan $\mathrm{p}<0.05$.

\section{HASIL DAN PEMB AHASAN}

Berdasarkan penelitian yang telah dilakukan secara mikrokopis terlihat gambaran kepadatan kolagen yang telah diamati. Gambaran histopatologi tersebut kemudian dihitung secara kuantitatif dan dirata-rata.

Tabel 1 menunjukkan hasil rata-rata dari setiap kelompok perlakuan. Hasil dari analisis data tersebut diketahui bahwa P1 dan P2 memiliki perbedaan nilai rata-rata yang signifikan dibandingkan dengan kelompok perlakuan lain yaitu $\mathrm{K}+, \mathrm{K}$ - dan $\mathrm{P}$ 3.

Gambar 1 menunjukkan gambaran histopatologi dari kelompok $\mathrm{K}+$ dan K-. Gambar histopatologi kelompok $\mathrm{K}+$ memiliki jumlah rata-rata kepadatan kolagen lebih banyak dari $\mathrm{K}$. Gambar 1 menunjukkan gambar histopatologi dari kelompok P1, P2 dan P3. Gambar histopatologi kelompok P1 memiliki jumlah ratarata kepadatan kolagen paling banyak dari P2 dan P3.

Kepadatan kolagen kelompok K- basis salep (vaseline flavum dan adeps lanae) menunjukkan persentase lebih rendah dibandingkan dengan $\mathrm{K}+, \mathrm{P} 1$, dan $\mathrm{P} 2$ namun lebih tinggi dibandingkan dengan P3. Basis salep tanpa ekstrak daun ketapang yang digunakan pada penelitian ini bertujuan untuk mengetahui apakah salep ekstrak daun ketapang memiliki fungsi pada penyembuhan luka. Vaseline flavum merupakan salah satu senyawa bersifat hidrokarbon yang tidak mudah hilang oleh air dan juga bersifat sebagai emolient dan moisturizer yang berperan untuk menjaga kelembapan pada kulit (Handayani dkk., 2016).

Adeps lanae yang digunakan sebagai basis salep merupakan suatu senyawa yang mengandung kholesterol tinggi dalam bentuk eter dan alkohol yang berfungsi sebagai lapisan penutup dan melunakkan kulit (Anief, 1997). Kepadatan kolagen pada K- lebih rendah dibandingkan dengan $\mathrm{K}+$ karena pada $\mathrm{K}$ - tidak terdapat zat aktif yang dapat mempengaruhi kepadatan kolagen sehingga persentase kepadatan kolagen dibawah $\mathrm{K}+, \mathrm{P} 1$ dan P2.

Kepadatan kolagen kelompok $\mathrm{K}(+)$ Bioplacenton $^{\circledR}$ menunjukkan persentase lebih tinggi dibandingkan dengan $\mathrm{K}$ - dan $\mathrm{P} 3$ namun lebih rendah dibandingkan P1 dan P2. Bioplacenton $^{\circledR}$ merupakan obat topikal yang mengandung $10 \%$ ekstrak plasenta dan 0,5\% neomisin sulfat (MIMS, 2016). Ekstrak placenta yang terkandung dalam Bioplacenton ${ }^{\circledR}$ mampu mempercepat neoangiogenesis, epiteliisasi, meningkatkan protein jaringan dan mampu meningkatkan sintesis kolagen (Navadiya et al., 2012).

Neomisin sulfat merupakan jenis antibiotik aminoglikosida spektrum luas yang berasal dari bakteri Streptomyces fradiae (National Cancer Institute, 2018). Neomisin sulfat memiliki peran meningkatkan aktivitas antimikrobial dengan cara memediasi penghambatan fungsi P RNase dari suatu organisme yang berperan dalam jalur pemrosesan tRNA (Blancard et al., 2016).

Kepadatan kolagen kelompok P1 (25\% salep daun ketapang) memiliki persentase paling tinggi dibandingkan dengan kelompok perlakuan yang lain dengan jumlah $90.32 \%$. Kepadatan kolagen yang tinggi karena kandungan senyawa kimia seperti flavonoid, tanin, saponin dan senyawaseyawa lain pada ekstrak daun ketapang (Kankia, 2014). Flavonoid pada ektrak daun ketapang 
Tabel 1. Rata-rata dan simpangan baku kepadatan kolagen pada setiap kelompok perlakuan

\begin{tabular}{cc}
\hline Perlakuan & Rata-rata $(\%) \pm$ Simpangan baku \\
\hline K- & $83.57^{\mathrm{a}} \pm 3.18$ \\
K+ & $84.52^{\mathrm{a}} \pm 3.49$ \\
P1 & $90.32^{\mathrm{b}} \pm 2.22$ \\
P2 & $86.77^{\mathrm{ab}} \pm 0.97$ \\
P3 & $83.36^{\mathrm{a}} \pm 3.20$
\end{tabular}

Superskrip berbeda pada kolom yang sama menunjukkan perbedaan signifikan $(\mathrm{p}<0.05)$

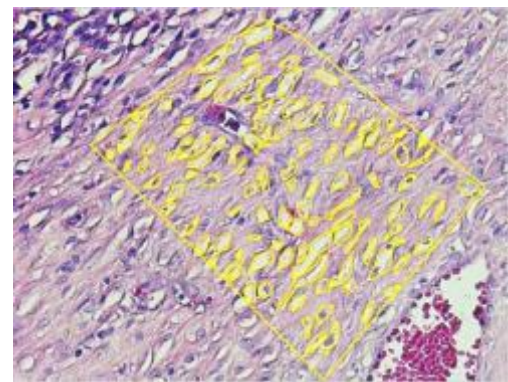

$\mathrm{K}-$

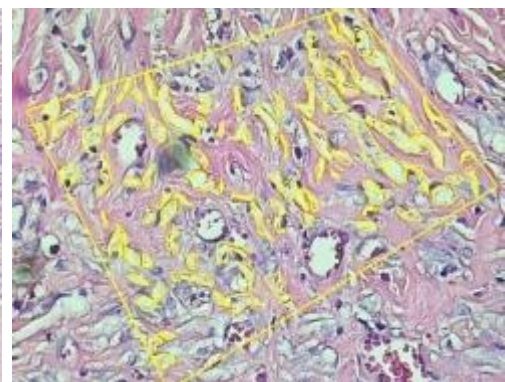

$\mathrm{K}+$

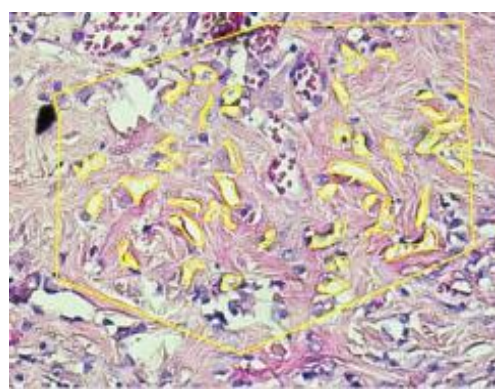

P1

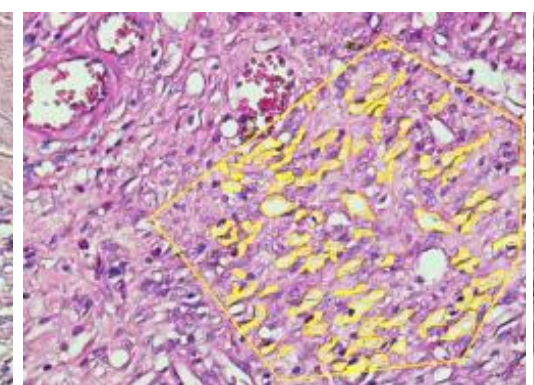

P2

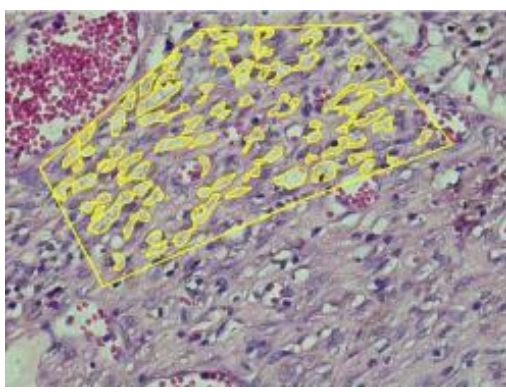

P3

Gambar 1. Gambaran ruang kosong adalah jaringan ikat kendor sedangkan kolagen ditunjukkan dengan warna sabut kemerahan

memiliki peranan penting dalam proses penyembuhan luka sebagai antioksidan (Balachandar et al., 2014). Flavonoid merupakan senyawa inhibitor enzim metalloproteinase. Metalloproteinase-1 (MMP-1, collagenase-1) memiliki peranan dalam percepatan pemecahan molekul kolagen pada kulit (Purnama dkk., 2019). Penghambatan aktivitas enzim metalloproteinase memungkinkan terjadinya peningkatan jumlah kolagen pada kulit (Elliot et al., 2007). Flavonoid juga mampu mempercepat proses perubahan prokolagen menjadi kolagen karena aktivitas flavonoid tersebut yang menginhibisi enzim metalloproteinase (Lim dan Kim, 2007). Sintesis kolagen membutuhkan senyawa yang menstabilkan induktor kolagen sehingga proses penyembuhan luka akan cepat terbentuk. Senyawa yang memiliki efek tersebut adalah tanin. Tanin merupakan senyawa dalam daun ketapang yang memiliki efek untuk menstabilkan proses pembentukan kolagen. Tanin memiliki efek mengurangi pembentukan jaringan parut akibat adanya aktivitas antibakteri dan agiogenik (Nikita dan Meera, 2014).

Senyawa lain seperti saponin juga memiliki peranan yang penting dalam proses penyembuhan luka khususnya pada fase inflamasi. Saponin mampu mempercepat fase inflamasi dengan menstimulasi merangsang vascular endothelial growth factor (VEGF) dan mempercepat proses penyembuhan luka (Rohmah dkk., 2016; Purnama dkk., 2018). Saponin juga mempengaruhi kolagen pada tahap awal perbaikan dengan menghambat produksi jaringan yang berlebih (Manoi, 2009) serta berfungsi sebagai antiseptik yang berfungsi untuk membunuh bakteri dan mencegah pertumbuhan mikroorganisme (Rahmawati, 
2014). Bahan lain yang turut membantu salep ekstrak daun ketapang bekerja dengan baik yaitu basis salep yang dicampurkan dengan salep berguna untuk menarik air sehingga luka cepat kering, tidak busuk dan menutupi luka (Anief, 1997).

Kepadatan kolagen kelompok P2 (50\% salep daun ketapang) memiliki persentase lebih kecil dibandingkan dengan P1 namun lebih besar dengan $\mathrm{K}-, \quad \mathrm{K}+$, dan $\mathrm{P} 3$ dengan jumlah persentase $86,77 \%$. Kepadatan kolagen pada P2 tidak terlalu berbeda jauh dengan $\mathrm{K}+$. Konsentrasi yang tinggi memungkinkan proses penyembuhan luka membutuhkan waktu yang sedikit lebih lama untuk membentuk kolagen pada daerah. Bioplacenton ${ }^{\circledR}$ dan dosis salep daun sukun $50 \%$ memiliki persentase kepadatan kolagen yang tidak terlalu jauh yaitu $86,77 \%$ dan $84,52 \%$ yang berarti kedua terapi tersebut memiliki pengaruh yang hampir sama dilihat dari data yang telah dianalasis.

Kepadatan kolagen kelompok P3 (100\% salep daun ketapang) memiliki persentase paling kecil dibandingkan dengan kelompok perlakuan yang lain yaitu dengan jumlah persentase sebesar $83,36 \%$. Proses kesembuhan pada P3 terhambat dapat disebabkan kadar flavonoid yang tinggi dapat menyebabkan penurunan daya antioksidasi. Kadar saponin yang tinggi juga mampu menyebabkan permeabilitas sel meningkat sehingga sel mengalami kematian. Hasil yang didapatkan bahwa luka yang diberi dengan salep ekstrak daun ketapang tanpa tambahan basis salep tidak menimbulkan kesembuhan karena konsentrasi salep yang pekat menimbulkan keropeng ketika kering sehingga menyumbat area luka dan ketika luka dibersihkan akan memunculkan pendarahan serta proses inflamasi akan semakin lama (Indraswary, 2014).

\section{KESIMPULAN}

Berdasarkan penelitian yang telah dilakukan salep daun ketapang berpengaruh dalam meningkatkan kepadatan kolagen pada luka bakar derajat II.

\section{UCAPAN TERIMA KASIH}

Peneliti mengucapkan terimakasih kepada Universitas Airlangga PSDKU Banyuwangi atas izin dan fasilitas yang telah diberikan untuk melaksanakan penelitian.

\section{DAFTAR PUSTAKA}

Anief, M. 1997. Ilmu Meracik Obat. Gajah Mada University Press, p10-17.

Balachandar, R., Saran, P.L., Ashok, K.K., Ragavi, A., Gurumoorthy, P. 2014. Antioxidant activity and wound healing potential of selected medicinal plants. JCHPS. 1(2), 100-300.

Balqis, U., Rasmaidardan, M. 2014. Gambaran Histopatologis Penyembuhan Luka Bakar Menggunakan Daun Kedondong (Spondias dulcis F.) dan Minyak Kelapa pada tikus Puth (Rattus norvegicus). Jurnal Program Studi Pendidikan Dokter Hewan Fakultas Kedokteran Universitas Syah Kuala.

Becker, J.M. 2006. Essentials of surgery. Philadelphia. Saunders Elsevier, p118-129.

Blanchard, C., Lauren, B., Andrew, B., Jennifer, C., Stephen, D., Paul, M.D. 2016. Neomycin Sulfate Improves the Antimicrobial Activity of Mupirocin-Based Antibacterial Ointments. Am. Soc. Microbiol., 60(2), 862872

Elliot, J., Woodward, J., Umarji, A., Mei, Y., Tona, A. 2007. The effect of surface chemistry on the formation of thin films of native fibrillar collagen. Biomat., 28(4), 576585 .

Frandson, R.D., Wilke, W.L., Anna, D.F. 2009. Anatomy and Physiology od Farm Animals : Seventh Edision. Colorado State University: Colorado. A John Wiley and Sons, Inc. 
Hamid, I.S., Aksono, E.B., Sukmanadi, M., Purnama, M.T.E. 2018. Antiangiogenesis activity test of tin leaf (Ficus carica L.) on the number of blood vessels and VEGF expression of chorioallantoic membrane of embryonated chicken eggs. Eur. J. Oncol. Pharm., 1(4), e00007.

Hamid, I.S., Ekowati, J., Purnama, M.T.E. 2019. Kaempferia galanga L. Inhibiting Effect on Vascular Endothelial Growth Factor (VEGF) and Cyclooxygenase-2 (Cox-2) Expression on Endothelium of Chorioallantoic Membrane. Indian Vet. J., 96(09), 80-82.

Handayani, F., Reksi, S., Henriko, N.K. 2016. Aktivitas Etanol Biji Pinang (Areca catecu L.) terhadap Penyembuhan Luka Bakar pada Kulit Punggung Mencit Jantan (Mus musculus). J. Ilmiah Manuntung, 2(2), 158.

Indraswary, R. 2014. Efek Konsentrasi Buah Adas (Foeniculum vulgare Mill) pada Epitelisasi Penyembuhan luka Gingiva Labial Tikus Sparague Dawly In Vivo [Skripsi]. Fakultas Kedokteran Gigi. Universitas Islam Sultan Agung.

Ivanalee, A.S. 2018. Efektivitas Sugar Dressing $(100 \%$ Gula) dalam Meningkatkan Kepadatan Kolagen pada Proses Penyembuhan Luka Bakar Buatan pada Kulit Tikus Putih (Rattus norvegicus) Jantan. J. Med. Vet., 1(3), 134-141

Kankia, H.I. 2014. Phytochemical screening and antibacterial activities of leaf extracts of Terminalia catappa (Umbrella Tree). IJSR. 3(12), 2658-61.

Lim, H., Kim, H. 2007. Inhibition of mammalian collagenase, matrix metalloproteinase-1,by naturally-occurring flavonoids . Planta Med., 73(12), 1267-1274.
Manoi., F. 2009. Binahong (Anredera cordifolia) Sebagai Obat. Badan Penelitian dan Pengembangan Pertanian. 15.

Maravelis, G., Voutsinou, A., Tsampa, N., Papasoglon, L.G. 2015. Management of An Extensive Partial and Full Thickness Skin Burn in A Dog with The Aid of Medical Honey. Hellenic J. Compan. Anim. Med., $4(2)$.

Mawarti, H. 2012. J. Ked. Brawijaya. 27(1).

MIMS. 2016. Bioplacenton. MIMS (C) 2016. // http://www.mims.com/myanmar/drug/info/bi oplacenton?type $=$ full [30 September 2018].

McGavin, M.D., Zachary, J.F. 2016. Pathologic Basis of Veterinary Disease. Elsevier Health Sciences.

Muhammad, A., Mudi, S.Y. 2011. Phytochemical screening and antimicrobial activities of Terminalia catappa. Leaf Extracts, 23(1).

National Cancer Institute. 2018. Neomycin Sulfate (Code C66227). Department of Health and Human Services, National Cancer Institute. USA./ /https://ncit.nci.nih.gov/ncitbrowser/Concept Report.jsp?dictionary=NCI_Thesaurus\&ns= ncit\&code $=$ C66227 [16 April 2019].

Navadiya., Sudhir, K., Yagnesh, L,. Vaghani., Mukesh, P.P. 2012. Study of Topical Placental Extract Versus Povidone Iodine and Saline Dressing in Various Diabetic Wounds. Departement of General Surgery, Surat Municipal Institute of Medical Education and Research (SMIMER). Surat. Nat. J. Med. Res., 2(4), 411-413.

Nikita, S., Meera, B. 2014. Tannin Extracted from Punica Granatum. Int. J. Engin. Res. Tech., 3(7), 479-81. 
Paramita, A. 2016. Pengaruh Pemberian Salep Ekstrak Daun Binahong (Anredera cordifolia (Ten) Steenis) terhadap Kepadatan Kolagen Tikus Putih (Rattus norvegicus) yang Mengalami Luka Bakar [Skripsi]. Fakultas Kedokteran Hewan Universitas Airlangga.

Purnama, M.T.E., Prastiya, R.A., Fikri, F., Saputro, A.L., Agustono, B. 2018. Ekstrak Etanol Kulit Buah Naga Menurunkan Indikasi Neoplasia Mammae Tikus Puth Berdasarkan Histopatologi dan Inhibitor Siklooksigenase-2. J. Vet., 19(1), 23-29.

Purnama, M.T.E., Rahmaningtyas, I.H., Pratama, A.R., Prastika, Z., Kartikasari, A.M., Cahyo, N.P.D. 2019. Tadpole serum activity (Rana catesbeiana) in caspase- 3 as a marker of the role of apoptosis and total cytotoxic $\mathrm{T}$ lymphocytes in albino rats' epithelial cells induced by neoplasia. Vet. World, 12(1), 63.

Rahmawati. 2014. Interaksi Ekstrak Daun Lidah Buaya (Aloe vera L.) dan Sirih (Piper bettle L.) Terhadap Daya Hambat Staphylococcus aureus secara In Vitro. J. Edu Bio Trop., 2(1), $121-186$.

Rohmah, S.N., Fuadah, D.Z., Girianto, W.R. 2016. Efektivitas Daun Petai Cina (Leucaena leucocephala) dan Daun Jarak Pagar (Jatropha cucas) terhadap Proses Penembuhan Luka Bakar Grade II pada Tikus Putih (Rattus norvegicus). J Ilmu Keperwatan, p20-33. 